University of Nebraska - Lincoln

DigitalCommons@University of Nebraska - Lincoln

Faculty Publications, UNL Libraries

Libraries at University of Nebraska-Lincoln

April 2000

\title{
Marketing Library Resources and Services to Distance Faculty
}

\author{
Kate Adams \\ University of Nebraska - Lincoln, kadams1@unl.edu \\ Mary Cassner \\ University of Nebraska - Lincoln, mcassner1@unl.edu
}

Follow this and additional works at: https://digitalcommons.unl.edu/libraryscience

Part of the Library and Information Science Commons

Adams, Kate and Cassner, Mary, "Marketing Library Resources and Services to Distance Faculty" (2000). Faculty Publications, UNL Libraries. 77.

https://digitalcommons.unl.edu/libraryscience/77

This Article is brought to you for free and open access by the Libraries at University of Nebraska-Lincoln at DigitalCommons@University of Nebraska - Lincoln. It has been accepted for inclusion in Faculty Publications, UNL Libraries by an authorized administrator of DigitalCommons@University of Nebraska - Lincoln. 


\title{
Marketing Library Resources and Services to Distance Faculty
}

\author{
Kate E. Adams \\ Mary Cassner \\ University of Nebraska-Lincoln
}

\begin{abstract}
SUMMARY. As academic libraries and librarians experience an increasingly complex higher education environment, it is essential to market library resources and services effectively. One component of a library's marketing plan for distance learners can be an assessment of the needs of distance faculty. Teaching faculty are influential in affecting student perceptions and their use of the library. This paper reports on an assessment of the needs of faculty who teach classes in distance graduate degree programs. Results from the survey provide strategic direction for delivering and marketing services to distance learners and distance faculty.
\end{abstract}

KEYWORDS. Marketing, faculty, distance learning, distance education, library services

In the past, academic libraries may have enjoyed a monopoly in providing information resources and services to students and faculty. However, the same cannot be said today. Users have a variety of options available to meet their research needs. Networked access and remote authentication allow users to access online databases from homes and work sites. With the click of a mouse, users can retrieve hundreds of hits from the World Wide Web, and e-mail or download full-text articles and documents. Users expect to have their research needs met instantaneously via the computer. A resulting impact for

[Haworth co-indexing entry note]: "Marketing Library Resources and Services to Distance Faculty." Adams, Kate E., and Mary Cassner. Co-published simultaneously in Journal of Library Administration (The Haworth Information Press, an imprint of The Haworth Press, Inc.) Vol. 31, No. 3/4, 2001, pp. 5-22; and: Off-Campus Library Services (ed: Anne Marie Casey) The Haworth Information Press, an imprint of The Haworth Press, Inc., 2001, pp. 5-22. 
academic libraries is the potential loss of what Wolpert (1998, p. 32) terms as "brand identity." Teaching faculty are using electronic technology to deliver courses to distance learners. Many higher education institutions offer full degree programs over the Internet and World Wide Web. Not infrequently, students and even faculty believe that the Web can effectively take the place of the academic library. With changing user expectations, academic libraries must move beyond the traditional service model to remain viable.

As academic libraries and librarians redefine their roles in the increasingly complex higher education environment, it is essential to effectively market library resources and services. Marketing "embraces an entire suite of management activities which include determining market niches, defining products and services, setting prices, promoting services, and building good public relations" (Olson \& Moseman, 1997, p. 20). The term "marketing" is defined as:

The organized process of planning and executing the conception, pricing, promotion and distribution of ideas, goods and services to create exchanges that will (if applicable) satisfy individual and organizations' objectives. Marketing collects and uses demographic, geographic, behavioral and psychological information. Marketing also fulfills the organization's mission and, like public relations, inspires public awareness and educates. (Marketing and public relations . . , 1999, p. 3)

Olson and Moseman (1997) believe that a critical component of any marketing activity is knowledge of customers as well as what they deem valuable and important. Cooper, Dempsey, Menon, and MillsonMartula (1998, p. 42) refer to library customers as "groupings of library constituents." In higher education, teaching faculty are an essential customer group. Instructors are influential in affecting student perceptions of, and their use of, the library. Faculty can require students to utilize scholarly journals, books, and reference materials from the libraries' print or electronic collections. They can refer students to reference librarians for assistance in search strategies and selecting databases. Instructors can also invite librarians to provide library instruction on a formal or informal basis.

One component of an academic library's marketing plan can be an assessment of the needs of distance faculty. In fall 1997, the authors had administered a brief survey to teaching faculty in conjunction with 
a survey of distance learners enrolled in the extended education master's degree program offered through the College of Human Resources and Family Sciences. Seven of the thirteen faculty responded to the five-question survey. Faculty required the same use of the library by extended students as by on-campus students. Respondents expected students to use books, journals, and the World Wide Web for their coursework. However, faculty reported limited contact with the library staff and services (Cassner \& Adams, 1998).

Like many other post-secondary education institutions, the University of Nebraska-Lincoln (known as UNL) has recently expanded its distance education curricula. As of fall 1999, UNL offers twelve master's degree programs and a doctoral program in administration, curriculum and instruction. Distance learner enrollment numbers around 650 graduate students. During the current semester, thirty faculty from seven colleges are teaching distance graduate courses. While the majority of distance courses are now delivered via the Internet and the World Wide Web, courses are also delivered via videotape, interactive television, videoconferencing, and e-mail.

The University Libraries' program for distance learners, established in 1990, includes remote access to 150 databases and 400 electronic journals, liaison librarian provision of reference assistance and instruction, as well as delivery of materials to distance students. In 1995, the Distance Education Coordinator position was increased to a .5 FTE assignment. The Distance Education Services page is located on the Libraries' main page at http://iris.unl.edu. It provides links to electronic reference, departmental liaison librarians, request forms via the Web or e-mail, electronic renewal, and circulation policies. Books are mailed directly to the distance learner, while journal articles may be mailed, faxed, or sent via the Internet. The Distance Education Coordinator works with distance administrative units to distribute subject-specific handouts to distance students every semester. One library support staff member fills distance requests from the Libraries' collections or through interlibrary loan. New distance students are also sent a personalized welcome message via e-mail. Liaison librarians frequently provide individualized reference assistance for distance students. Several liaison librarians are members of class listservs and are aware of class assignments.

The Distance Education Coordinator mails subject-specific handouts to distance faculty and contacts faculty individually via e-mail 
prior to start of the semester. The Coordinator also sends generic messages during the semester, for example, to remind faculty of the distance education page or alert them to new databases. Liaison librarians also contact the teaching faculty near the beginning of the semester about specific course assignments.

Given the expanded number of distance graduate programs at UNL, the authors chose to conduct another survey of distance teaching faculty. It was hoped that a more extensive survey of distance teaching faculty with a broader population could provide feedback as the Libraries assess the needs of faculty who teach distance courses. Specific research questions formulated prior to writing the survey included:

To what degree are faculty satisfied with library resources and services offered to distance students?

To what degree are faculty aware of the scope of library resources and services available to distance students?

To what degree are faculty satisfied with the services of the Libraries' Distance Education Coordinator and the Subject Specialist/Liaison Librarian for their department?

Have faculty invited the Subject Specialist Librarian or the Distance Education Coordinator to give instruction to extended education students? If so, what delivery method was used?

What is the level of usage of selected resources for course-related research?

To what degree do faculty require the use of library resources for extended education students in comparison to the classes they teach on campus (not through extended education)?

What services and resources would faculty suggest the Libraries offer to distance students?

What services and resources would faculty suggest the Libraries offer to instructors of extended education courses?

What factors might impede faculty use of UNL services and/or resources? 
However, the survey was also aimed with a broader purpose: to market library resources and services to distance faculty. The survey was conducted not only to solicit faculty input but also to increase awareness of library resources and services offered to distance instructors and extended education students. The wording of the survey questions served as an educational tool by enumerating library resources and services available to distance faculty and students. The URL for the Libraries' home page was provided.

\section{REVIEW OF THE LITERATURE}

The review of the literature showed some surveys of distance faculty. Often the surveys have been conducted in tandem with surveys of distance students, and have focused on instruction and library skills. Behrens (1993, p. 11) characterized faculty attitude towards the need for students to have library skills as "a less obvious but very real obstacle." She concluded from her study of the University of South Africa that lecturers were unaware of the scope and role of library skills in the learning process. Ruddy (1993) asked faculty about their requirements for student use of the library. She reported contradictory results between professed need for extensive library use and the class assignments.

Lebowitz (1993) surveyed faculty who taught off-campus students to determine faculty expectations of student library use as well as future needs. Respondents gave low rankings for the necessity of providing off-campus students with instruction on library resources and reference. Craig and DuFord (1995) reported that while over $80 \%$ of the graduate faculty required the use of library services and materials to complete course assignments, only $35 \%$ responded that they offered library instruction.

The theme of the 1998 summer issue of Library Trends was service to remote users. Cooper et al. (1998) conducted informal e-mail surveys and phone interviews with six distance faculty. They concluded that while the teaching faculty expectation is for distance learners to use an academic library, faculty "make no distinction between the skills needed by a student on campus and one at a remote site" (p. 57).

Landrum (1987) noted a decade earlier that "faculty attitudes are the most significant factor in affecting students' use of the library" (p. 15). She urged librarians to survey faculty for their current use of libraries 
as well as future needs, as part of analysis prior to designing a market plan.

\section{METHOD}

Data for the study were collected by a self-administered survey distributed in fall 1999. Surveys were sent to eighty faculty, the entire population, who had taught one or more graduate distance courses at the University of Nebraska-Lincoln during each fall semester and summer session between fall 1997 and fall 1999. Courses taught are master's graduate degree programs offered at a distance: Business Administration, Education, Engineering (beginning fall 1999), Entomology, Human Resources and Family Sciences, Industrial and Management Systems Engineering, Journalism and Mass Communications, Manufacturing Systems Engineering, and Textiles, Clothing and Design. Faculty from Computer Sciences and Engineering were included, although the master's degree is no longer offered via distance. Faculty who teach in a distance doctoral program in Administration, Curriculum and Instruction were included. Also in the study were faculty who teach "solo" distance graduate courses that are not part of a graduate curriculum offered entirely at a distance.

Faculty members were given the opportunity to respond to the survey via e-mail or surface. A three-step procedure was employed with an introductory letter and survey sent via e-mail in October 1999 to the population of eighty instructors. Faculty were given the option of returning the completed survey via e-mail or printing the survey and returning it via campus mail. Two weeks after the e-mail survey was sent, the investigators mailed print cover letters and surveys as well as self-addressed envelopes to faculty members who had not yet responded. After ten days, faculty who had not responded were sent another letter and survey via e-mail. Thirty-nine faculty, or $50 \%$, returned the surveys via e-mail (27) or surface mail (12). Three surveys were not usable.

The instrument used in the study was a self-administered survey designed by the investigators. [See Appendix for sample survey.] The format included a combination of open- and close-ended questions. Participants had the opportunity to add comments in each of the eight major questions. Close-ended questions included Likert rating scales and categorical (yes/no) scales. The first question focused on the 
degree of satisfaction with library resources and services offered to distance students. Services and resources were grouped into categories, such as electronic resources, obtaining materials, and document delivery. Following this were questions related to satisfaction with assistance from the Libraries' Distance Education Coordinator and the subject specialist/liaison librarian assigned to the faculty member's academic department. Another set of questions focused on library instruction for extended education students. Faculty were also asked to specify whether they required distance learners to use library resources and services more extensively, the same, or less than on-campus students. Questions sought suggestions for additional library resources and services for both distant students and faculty. As a final question, faculty were asked what might impede their use of library services or resources.

Survey data were analyzed by the investigators and summary sheets prepared. For close-ended questions, percentages of each response were determined. "No response" to questions (lack of any response) was also noted. All comments by faculty, whether solicited or not solicited, were recorded.

\section{RESULTS}

Overall, faculty were satisfied with library resources and services offered to their distance students. They indicated a high degree of satisfaction with the Libraries' Distance Education Coordinator as well as the subject specialist/liaison librarian assigned to their particular academic department. At the same time, very few faculty had invited librarians to provide instructional presentations for their extended education students. Many faculty often require distant students to use books, journal articles, and/or the World Wide Web for class assignments. A slight majority of faculty require approximately the same use of library resources for distance students as they do for on-campus courses they teach. Some faculty provided responses to questions regarding suggestions for additional services or resources that might be offered to them or to their distant students. Likewise, some faculty noted impediments to their use of library services and resources. Many instructors also included additional comments at the end of the survey.

The first group of questions involved faculty satisfaction with li- 
brary resources and services offered to their distance students. [Note: All percentages given in these results refer to respondents who indicated their degree of satisfaction. Percentages do not take into account those who marked "not observed" or who did not respond to the question.] Seventy-five percent of faculty were very satisfied with the University Libraries' home page, while $23 \%$ were somewhat satisfied. Sixty percent of survey respondents were very satisfied with the Libraries' online catalog, while $36 \%$ were somewhat satisfied. Similarly, $71 \%$ of faculty were very satisfied with the Libraries' Distance Education Services' Web page and 29\% were somewhat satisfied.

Faculty satisfaction with electronic indexes was lower. Twentythree percent of respondents were very satisfied with general procedures for remote access to use restricted databases (proxy server). Fifty-three percent were somewhat satisfied, $18 \%$ were somewhat dissatisfied, and $6 \%$ were very dissatisfied with procedures for using the proxy server. In rating degree of satisfaction with journal article database selection, $26 \%$ were very satisfied, $63 \%$ somewhat satisfied, and $10 \%$ somewhat dissatisfied. Seventeen percent of respondents were very satisfied with the Libraries' electronic journals with 59\% somewhat satisfied, $19 \%$ somewhat dissatisfied, and 5\% very dissatisfied. Thirty-six percent of faculty were very satisfied with the Libraries' Internet Resources Collection, which is a collection of selected Web sites arranged by subject, while 64\% were somewhat satisfied. There was a high level of satisfaction with the Libraries' electronic reference service. Eighty-two percent of survey respondents were very satisfied with the electronic reference service and $18 \%$ were somewhat satisfied. Nine faculty members included narrative comments about electronic resources. Most of the narrative responses expressed pleasure with the Libraries' electronic resources or noted that they were not aware of these resources.

A section of the survey involved convenience and ease of use in obtaining print materials from the University Libraries. An equal number of respondents (44\%) were very satisfied or somewhat satisfied in using the Web to request photocopied articles and book loans. Twelve percent, however, indicated they were very dissatisfied with this service. Seventy-three percent of faculty were very satisfied with requesting materials via e-mail, $18 \%$ somewhat satisfied, and $9 \%$ somewhat dissatisfied. Seventy-five percent were very satisfied with use of fax to request materials and $25 \%$ were somewhat satisfied. Sixty-one percent 
were very satisfied and $23 \%$ were somewhat satisfied in using the mail to request materials. However, $16 \%$ expressed some dissatisfaction with this service.

Three survey questions related to degree of satisfaction regarding timeliness of delivery of library materials to students. Sixty-seven percent of faculty were very satisfied with mail delivery of photocopied articles to students. Twenty-five percent were somewhat satisfied with this service while $8 \%$ were very dissatisfied. An identical number $(67 \%)$ of faculty were very satisfied with fax delivery of photocopied articles to their students. However, 33\% were somewhat satisfied. Fifty-eight percent of faculty respondents stated they were very satisfied with the timeliness of delivery of books to their students via mail. However, $17 \%$ indicated they were somewhat satisfied, $8 \%$ were somewhat dissatisfied, and $17 \%$ were very dissatisfied.

Students enrolled in classes through the University of NebraskaLincoln have borrowing privileges at other academic libraries in $\mathrm{Ne}$ braska. Faculty were asked to assess their level of satisfaction with this service. Responses indicated that $33 \%$ were very satisfied with this service, $50 \%$ were somewhat satisfied, and $17 \%$ were very dissatisfied with this service.

Only five faculty members provided optional comments regarding obtaining print materials. Four indicated that they did not have information pertinent to rating this service. One faculty member stated that although the library staff had been accommodating, he/she had a problem related to the policy of recalling books that distance students may have checked out.

The second broad area of survey questions related to faculty satisfaction with the assistance they have received from librarians whose assignments included serving extended education students. The survey indicated that faculty were very satisfied with the Libraries' Distance Education Coordinator: responsive to students' requests for assistance (94\%); available during appropriate service hours (93\%); willingness to provide instructional presentations such as library instruction (79\%); and willingness to provide descriptive handouts in print format (87\%). Eight optional comments related to the Distance Education Coordinator were made. Several were highly complimentary while other faculty indicated they do not use this service.

Faculty indicated that they were satisfied with the services provided by the Subject Specialist Librarian assigned to their specific academic 
department. Respondents rated as "very satisfied": responsive to students' requests for assistance (88\%); available during appropriate service hours (94\%); and, willingness to provide library instruction (93\%). Eight respondents made comments regarding Subject Specialist Librarians. Most expressed pleasure with the level of service provided by their specific departmental librarian. One indicated that he was unaware of this individual's name.

The third area of questions asked faculty whether librarians had provided presentations (library instruction) for their extended education students. Only $15 \%$ of faculty stated that they had invited the Subject Specialist/Liaison Librarian to give instruction to their distance students. Of those that marked "yes," instruction was provided by a variety of means: satellite television, e-mail or class listserv, videotape, and live appearance at class. Seventeen percent of faculty indicated they had invited the Distance Education Coordinator to provide instruction for their extended education students. The instruction was provided through satellite television, in-class presentations, U.S. mail, and written materials that were scanned into programs. Two faculty comments indicated that the presentations were "good" or "helpful" while another stated that she was unaware that librarians could provide this service.

The fourth question related to the frequency that faculty require their students to use resources for course-related research for their extended education classes. Books were used: very often $(31 \%)$, often $(13 \%)$, sometimes $(22 \%)$, not often $(6 \%)$, or not at all $(28 \%)$. The frequency of journal article usage was: very often (33\%), often (15\%), sometimes (21\%), not often (6\%), or not at all (24\%). Survey respondents stated that their usage of the World Wide Web for student courserelated research was: very often $(43 \%)$, often $(24 \%)$, sometimes $(12 \%)$, not often $(9 \%)$, or not at all $(12 \%)$. The required usage of electronic journals was: very often $(12 \%)$, often $(12 \%)$, sometimes $(30 \%)$, not often $(12 \%)$, not at all $(33 \%)$. There was very little usage of electronic reserves: very often $(9 \%)$, often $(6 \%)$, sometimes $(6 \%)$, not often $(9 \%)$, or not at all $(70 \%)$. Eight faculty provided additional comments. These included a wide spectrum of replies including comments that students are not required to use the library, as well as that students are always expected to make use of library resources and services.

Instructors were also asked whether the extended education classes 
they taught required more or less use of library resources in comparison to courses they taught on campus. The results were more extensive use of library resources [by extended education courses] (13\%), less extensive use of library resources (32\%), and approximately the same use of library resources (55\%). Seven faculty included optional comments. These ranged from a comment that students are not asked to use the library to a comment that students are always expected to make use of library resources and services.

The sixth question asked faculty to suggest additional services or resources they would like the Libraries to offer to extended education students. Several of the fifteen respondents indicated they had no suggestions at this time, that their courses did not require the use of the library, or that they were unaware of the services offered by the Libraries. One comment stated, "You are doing a fine job with our students at the present time-they rave about the service!!!" Another faculty member stated, "Just try to stay up with the ever changing technology and make the systems as simple as possible."

The next question asked respondents to suggest additional resources or services they would like the Libraries to offer to them as faculty members teaching extended classes. Faculty provided twelve comments. Many had no further suggestions. Examples of other comments include "more awareness regarding what is available" and the addition of more electronic journals.

Faculty were also asked what might impede their use of UNL Libraries' services and/or resources. The fifteen responses varied from "nothing" to "lack of knowledge of what services are available" to lack of time or knowledge of the latest technology. One faculty member indicated a problem accessing the Libraries' catalog using a particular browser. Another respondent mentioned a difficulty in accessing a particular index, which uses an ICA client that must be installed.

At the end of the survey, faculty were given the opportunity to add comments. Fourteen comments were provided. Some respondents remarked that their courses did not require the use of library resources. One faculty member stated, "just responding to this survey made me mad that I did not think of using your services before now." Others were complimentary, such as "I think that you've done a great job-the cooperation of the library staff has certainly made our distance education programs more successful than they would have been without your help and innovations." 
Input was also solicited from several administrators whose responsibilities include distance education. Administrators were asked to specify what might impede faculty use of the UNL Libraries' services and/or resources. One administrator noted that faculty are not fully aware of what is available to them. Faculty usually learn of the Libraries' distance services by word of mouth, from other faculty. Experienced distance faculty may refer new distance faculty to the Distance Education Coordinator. Administrators noted the challenge of keeping up with the rapid changes in technology. Timeliness of materials delivery was deemed important.

\section{DISCUSSION}

The percentage rate of returned surveys (50\%) was disappointing although not unexpected. Of the thirty-nine faculty who returned the survey, six or seven typically did not answer the majority of questions. Of surprise was the large number of respondents who indicated "not observed" in response to questions related to basic resources. For example, almost $20 \%$ of distance faculty marked "not observed" when asked to rate their degree of satisfaction with the Libraries' home page as well as the online catalog.

Of prime importance to customers in the business world are two basic expectations, namely promises of service that are kept and a solid performance by the product and the company. However, customers may not consider that some problems are beyond the company's control. In academic libraries, technology represents one such example. Survey findings showed lower levels of satisfaction with the proxy server technology. In many cases, the proxy server/authentication process is administered outside the library. Librarians need to communicate clearly to distance faculty and distance learners the extent of library responsibility for proxy server and other system problems. Communication should clarify expectations (Cooper, 1998). Survey dissatisfaction with databases may similarly reflect dissonant expectations regarding content and scope of databases. Another explanation for some dissatisfaction could be the limited number of full-text databases currently available. As some respondents stated, distance learners are dependent on full-text databases due to their physical distance from the library. Distance faculty expect the library to keep up with changing technology and make it user friendly. 
While technology has expanded and enhanced information access, it has also caused depersonalization (Cooper, 1998). Librarians can offset depersonalization by putting a human face on the virtual library for faculty as well as students. Distance librarians can bring their knowledge of information resources and organization, and expertise in information technology, to the forefront in collaboration with teaching faculty. Librarians, instructional designers, and teaching faculty can form a powerful partnership in delivery of distance courses. Yang and Frank (1999) suggest strategies that distance librarians can adapt in partnering with distance faculty.

\section{CONCLUSION}

The authors' earlier survey had been conducted in conjunction with a detailed survey of distance students in one academic college (Cassner \& Adams, 1997). The current survey, meanwhile, was larger in population and covered all colleges currently offering distance graduate programs at the University of Nebraska-Lincoln. The survey instrument covered the range of distance library services and resources. It was designed to assess the needs of faculty who teach courses in distance graduate degree programs. The authors defined needs as degree of satisfaction with library resources and services offered to distance faculty and learners. Faculty input for additional services was sought. The instrument also served as a feedback mechanism for degree of usage of library resources that support distance courses. An additional purpose of the survey was instructional in nature. The survey provided an overview of available services and resources. Thus, it was also developed as a marketing strategy.

Survey results indicated, overall, a high degree of faculty satisfaction with library services and resources. Faculty offered some comments on services and resources as well as suggestions for future direction. Generally, comments were centered on keeping up with technological developments as well as increasing the availability of full-text databases. The instrument also served to market the multiple library resources and services.

As academic libraries continue to move from the ownership model to an access environment, assessment measures such as faculty user satisfaction must be explored (Saunders, 1999). In addition to survey instruments, focus groups and other interview techniques can elicit 
user input for shaping the library's future direction, while fostering communication and offering an element of personalization.

Librarians, as active participants in the higher education community, can offer their expertise in instruction and electronic technology to enhance institutional success.

\section{REFERENCES}

Behrens, S. J. (1993). Obstacles to user education for off-campus students: Lecturers' attitudes to library skills. In C. Jacob (Comp.), The Sixth Off-Campus Library Services Conference Proceedings: Kansas City, Missouri, October 6-8, 1993 (pp. 11-23). Mount Pleasant, MI: Central Michigan University.

Cassner, M., \& Adams, K. (1998). Instructional support to a rural graduate population: An assessment of library services. In P. S. Thomas \& M. Jones (Comps.), The Eighth Off-Campus Library Services Conference Proceedings: Providence, Rhode Island, April 22-24, 1998 (pp. 117-130). Mount Pleasant, MI: Central Michigan University.

Cooper, R., Dempsey, P. R., Menon, V., \& Millson-Martula, C. (1998). Remote library users-Needs and expectations. Library Trends, 47(1), 42-64.

Craig, M. H., \& DuFord, S. (1995). Off-campus faculty perception of the value of library user education. In C. J. Jacobs (Comp. ), The Seventh Off-Campus Library Services Conference Proceedings: San Diego, California, October 25-27, 1995 (pp. 69-73). Mount Pleasant, MI: Central Michigan University.

Landrum, M. C. (1987). Marketing library services to faculty. Colorado Libraries, $13,15-16$.

Lebowitz, G. (1993). Faculty perceptions of off-campus student library needs. In C. J. Jacob (Comp.), The Sixth Off-Campus Library Services Conference Proceedings: Kansas City, Missouri, October 6-8, 1993 (pp. 143-154). Mount Pleasant, MI: Central Michigan University.

Marketing and public relations activities in ARL libraries: A SPEC kit. (1999). Washington, DC: Association of Research Libraries, Office of Leadership and Management Services.

Olson, C. A., \& Moseman, S. S. (1997). Overlooked? Understaffed? Don't stop marketing! Information Outlook, 1, 20-23.

Ruddy, Sr. M. (1993). Off-campus faculty and student's perceptions of the library: Are they the same? In C. J. Jacob (Comp.), The Sixth Off-Campus Library Services Conference Proceedings: Kansas City, Missouri, October 6-8, 1993 (pp. 227-240). Mount Pleasant, MI: Central Michigan University.

Saunders, L. M. (1999). Human element in the virtual library. Library Trends, 47(4), 771-787.

Wolpert, A. (1998). Services to remote users: Marketing the library's role. Library Trends, 47(1), 21-41.

Yang, J. \& Frank, D. (1999). Working effectively with scholars: A key to academic library success. Georgia Library Quarterly, 36(2), 9-12. 


\section{APPENDIX}

\section{Survey of UNL Faculty Who Have Taught Extended Education Classes}

1. How satisfied are you with the following library resources and services offered to your distance students?

\section{Very Somewhat Somewhat Very Not Satisfied Satisfied Dissatisfied Dissatisfied Observed}

\section{ELECTRONIC RESOURCES}

UNL Libraries' Home Page

[http://iris.unl.edu]

UNL Libraries' [online] Catalog

[to search for books, journal titles]

UNL Distance Education Services

Indexes/Full-Text Materials

General procedures for remote access to use restricted databases

[proxy server]

Database selection

[journal article databases that

support your curriculum]

Electronic Journals

[e-journals available via Web]

Internet Resources Collection

[collection of selected Web sites

arranged by subject]

Electronic reference service

[to ask a reference question via IRIS]

Optional comments regarding Electronic Resources:

\section{OBTAINING PRINT MATERIALS}

Requesting Photocopied Articles and/or Book Loans [convenience and ease of use]

Via Web

Via e-mail

Via fax

Via mail

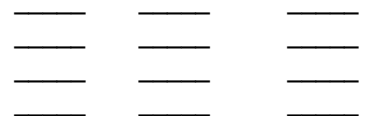

Delivery of Photocopied Articles to Students [timeliness]

Via mail

Via fax 


\section{APPENDIX (continued)}

Delivery of Books to Students [timeliness]

Via mail

Reciprocal borrowing from other Nebraska libraries [students have borrowing privileges at other academic libraries in Nebraska]

Optional comments regarding Obtaining Print Materials:

2. How satisfied are you with assistance from librarians whose duties include serving your extended education students?

\section{Very Somewhat Somewhat Very Not Satisfied Satisfied Dissatisfied Dissatisfied Observed}

\section{LIBRARIES' DISTANCE EDUCATION COORDINATOR}

[Coordinates Library services to extended education students and faculty]

-Responsive to students' requests for assistance

-Available during appropriate service hours

-Willingness to provide instructional presentations [library instruction]

-Provides descriptive handouts in print format

Optional comments regarding Libraries' Distance Education Coordinator:

\section{SUBJECT SPECIALIST/LIAISON LIBRARIAN FOR YOUR DEPARTMENT}

[Librarian assigned to your academic department]

-Responsive to students'

requests for assistance

-Available during appropriate service hours

-Willingness to provide instructional presentations [library instruction] 
Optional comments regarding Subject Specialist/Liaison Librarian for Your Department:

3. Have librarians provided instructional presentations for your extended education students? Have you invited the Subject Specialist/Liaison Librarian to give instruction to your extended education students?

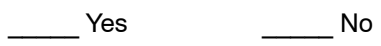

If you answered "yes," was the instruction provided by the Subject Specialist/Liaison

Librarian via:

E-mail/listserv

Satellite television

Other (please specify delivery mode)

Have you invited the Distance Education Coordinator to give instruction to your extended education students?<smiles>[AsH3]</smiles>

If you answered "yes," was the instruction provided by the Distance Education

Coordinator via:

E-mail/listserv

Satellite television

Other (please specify delivery mode)

Optional comments regarding instructional presentations for your extended education students:

4. How frequently have you required your students to use the following resources for courserelated research for your extended education classes?

\section{very often often sometimes not often not at all}

Books

Journal Articles

World Wide Web

Electronic Journals

[e-journals available via Web]

Electronic Reserves

Other (please specify resource) 


\section{APPENDIX (continued)}

Optional comments regarding student use of resources for course-related research:

5. In comparison to the courses you teach on campus (not through extended education), do your extended education courses usually require:

More extensive use of library resources

Less extensive use of library resources

Approximately the same use of library resources

Optional comments regarding use of library resources for your extended education courses:

6. What additional services and/or resources would you suggest the Libraries offer to extended education students?

7. What additional services and/or resources would you suggest the Libraries offer to you as a faculty member teaching extended education classes?

8. What might impede your use of UNL Libraries' services and/or resources?

9. Please add additional comments, if you choose. 